\title{
Development of prototyping as an alternative for trauma reconstruction in a common sloth limb (Bradypus variegatus)
}

\section{Desenvolvimento de prototipagem como alternativa de reconstrução de trauma em membro de preguiça-comum (Bradypus variegatus)}

\author{
Priscila Melo Santos ${ }^{1}$, Sandra Peres Ferreira ${ }^{1}$, Renato Frosch ${ }^{1}$, Georgea Jarreta ${ }^{1}$, Erica Elias \\ Baron $^{1}$, Juliana Plácido Guimarães ${ }^{1 *}$
}

\begin{abstract}
Specimens of Bradypus variegatus are commonly found with thoracic limbs lesions, victims of electric shock sit-ins or trampling, presenting injuries such as loss of claws and fractures, compromising their locomotion and ability to pick up their food causing the animal to die. The aim of this study was to perform a prototyping of the common sloth limb (Bradypus variegatus), using radiographic images, digital modeling software and 3D printing, for future implantation in common sloths who suffered trauma in thoracic limb. Thus, it was intended to compensate for the absence of bone structure by rapid prototyping, establishing at least the possibility of support and to obtain food.
\end{abstract}

Keywords: Bradypus variegatus; Thoracic limb; Radiology; Prototyping;

\section{RESUMO}

Exemplares de Bradypus variegatus são comumente encontrados com lesões em membros torácicos, vítimas de choques elétricos ou atropelamentos, apresentando ferimentos como perda das garras e fraturas, comprometendo sua locomoção e capacidade de apanhar seu alimento, o que, por sua vez, acaba por levar o animal a óbito. O objetivo desse estudo foi realizar uma prototipagem de membro de preguiça-comum (Bradypus variegatus), utilizando imagens radiográficas, softwares de modelagem digital e impressão 3D, para futura implantação em preguiças-comum que sofreram trauma em membro torácico. Dessa forma, pretendeu-se a compensação da ausência da estrutura óssea por prototipagem rápida, estabelecendo, ao menos, a possibilidade de apoio e apreensão do alimento.

Palavras-chave: Bradypus variegatus; Membro torácico; Radiologia; Prototipagem;

\footnotetext{
${ }^{1}$ São Judas University Center

*E-mail: juvetpg@yahoo.com.br
} 


\section{INTRODUÇÃO}

The number of wild animals moving to urban or urbanized areas is increasing and this occurs because of anthropic actions (CURITIBA, 2012), where, due to these factors, several biological models, including sloths, are threatened (AZARIAS et al., 2006).

Because it is a species with arboreal habits, sloths are susceptible to electric shocks and, therefore, are frequent victims for veterinary intervention (PETRUCCI et al., 2009; ARAÚJO et al., 2010). As pointed out by Correia Júnior and Corrêa (2013), the same is used for individuals who inhabit forest fragments cut by highways or roads, which end up being victims of trampling, after attempting to cross the roads towards the other part of the fragment, and in both situations specimens have as a result serious injuries such as loss of claws and fracture of limbs, or even death.

According to Petrucci et al. (2009), Araújo et al. (2010), the most common causes of veterinary interventions in these animals, when found in urban areas, are electric shocks, when, through trees, they reach high voltage poles, located on the edge of forest, becoming victims of electrical discharges, when moving through the treetops.

With technological advances, it was possible to apply some innovations, so that in the areas of health, 3D printing or rapid prototyping has been used in human medicine, veterinary medicine and dentistry, with production of biomodels (SEARS et al., 2016) and, for this, 3D printers have emerged as a favorable option for construction of complete anatomical parts, in order to establish and validate the best positioning and treatment (SHIN-WOOK et al., 2014).

Three-dimensional models of bone regions are not easy to obtain, mainly due to their geometry complexity. Thus, the construction of images can be done from two distinct forms: with the use of computed tomography, using software that unites twodimensional figures formed by this methodology and transform them into 3D images (JÓIA FILHO, 2008), or with a 3D scanner, and this method is widely used for presenting good spatial resolution and being economically accessible (SCAGLIUSI, 2015).

As filament options, there are several materials, with characteristics, such as quality of finish and resistance, which vary according to the intended use. Among others, Acrinolitrin Butadiene Styrene (ABS), Lactic Polyacid (PLA) and Polyethylene Terephthalate with Glycol (PETG) should be mentioned. 
Frosch (2021) mentions that while ABS and PETG have greater durability, PLA reaches $60 \mathrm{MPa}$ of maximum effort, on the other hand, ABS and PETG reach at most the level of $50 \mathrm{MPa}$ of this technical characteristic.

The present study aimed to perform a prototyping of common sloth limb (Bradypus variegatus), using radiographic images, digital modeling software and 3D printing, for future implantation in specimens that suffered trauma to thoracic limb.

\section{MATERIAL AND METHOD}

Two specimens of B. variegatus were used, one from São Judas Tadeu Wild Animal Screening Research Center (Centro de Pesquisa e Triagem de Animais Silvestres - CEPTAS), in Cubatão/SP, and one from Engenheiro Tércio Augusto Garcia Ecological Park (Parque Ecológico Engenheiro Tércio Augusto Garcia), in São Vicente/SP, for rehabilitation and subsequent release.

Initially, a clinical examination was performed on the animals and then, they were submitted to radiographic examination of thoracic limb for evaluation and recording of their bone morphology. For this, animals were positioned in right and left lateral decubitus for radiography in midlateral projections, and ventral decubitus for dorsopalmar projection.

From the acquisition of radiographic images, the procedure was divided into stages, the process of elaboration of prosthesis model of claws of this species was initiated, with support of the Maker Space laboratory of the São Judas Tadeu University Center - Unimonte Campus, using digital modeling software.

Inkscape ${ }^{\circledR}$ (an image editing software) was used to create the claw of the animal. With the same program, vectorization of this structure was performed in $2 \mathrm{D}$ from the radiographic image. After obtaining the image of the contour of claws in 2D, it was transferred to Blender ${ }^{\circledR}$ program, in which transformation to $3 \mathrm{D}$ and triplicate of the structure occurred, creating the three-claw digital model. With the use of geometric shape from a cube, a glove was formulated, in which claws were inserted, forming the model of the prosthesis in three-dimensional format.

With digitally generated 3D model, a 3D printing of the physical model of the prosthesis was performed, using Cliever CL2 Pro Plus ${ }^{\circledR}$ printer, which has as its 
manufacturing principle a technique named Fused Deposition Modeling - FDM, characterized by the overlap of castings, for this research, thermoplastic polylactic acid (PLA) with a height of $0.2 \mathrm{~mm}$. After this process, the prosthesis received a finish of its shape and the orifices were filled with 3D Pen equipment ${ }^{\circledR}$.

It is worth to highlight the intentionality of the use of free softwares, since these are technological tools that provide an opportunity to democratize access to digital modeling in several areas of knowledge.

\section{RESULTS AND DISCUSSION}

Rapid prototyping is on the rise in the health area, where it has been used in human medicine, veterinary medicine, and dentistry, with production of biomodels (Sears et al. 2016).

According to Grando (2005), rapid prototyping is a technology that allows the direct relationship between real anatomy and the model to be generated, and for this reason this work proposed to develop a prototyping of the claws of the species Bradypus variegatus, since these animals are often found ran over and electrocuted, and the most affected area is usually the thoracic members and claws, a fundamental structure for the survival of a species that lives in trees.

On radiography of the extremity of thoracic limb, carpal bones, metacarpic bones, proximal, middle and distal phalanges and claws of a healthy animal (Fig. 1A and B) and of an animal that was electrocuted with claw injury are observed. It is noted that the species has five metacarpals, metacarpals II, III and IV developed and metacarpals I and V rudimentary (Fig. 1), a data compatible with that found by Freitas et al. (2017) in pelvic limb research for that species.

From the radiographic images of the claws of $B$. variegatus, an image editing software (Inkscape ${ }^{\circledR}$ ) was used to perform the vectorization of this structure in 2D (Fig. 2A). After obtaining the image of the contour of the claws in 2D, it was transferred to Blender ${ }^{\circledR}$ program, in which the transformation to $3 \mathrm{D}$ and triplicate of the structure occurred, creating the image of three claws. With the use of the geometric shape from a cube, a glove was formulated, in which the claws were inserted, forming the model of prosthesis in three-dimensional format (Fig. 2B). 
Fig. 1- A: Radiographic image of the extremity of the left thoracic limb of a Bradypus variegatus, healthy animal, ventral dorsum incidence. B: Radiographic image of the extremity of the left thoracic limb of a Bradypus variegatus, electrocuted animal, dorsopalmar incidence. Legend: 1radio; 2- ulna; 3- radial carpal bone; 4- intermediate carpal bone; 5- ulnar carpal bone; 6- bone carpal accessory; 7- metacarpic bone I; 8- metacarpic bone II; 9- metacarpic bone III; 10metacarpic bone IV; 11 - metacarpic bone V; 12- proximal phalanx; 13- middle phalanx; 14- distal phalanx; 15- claws.

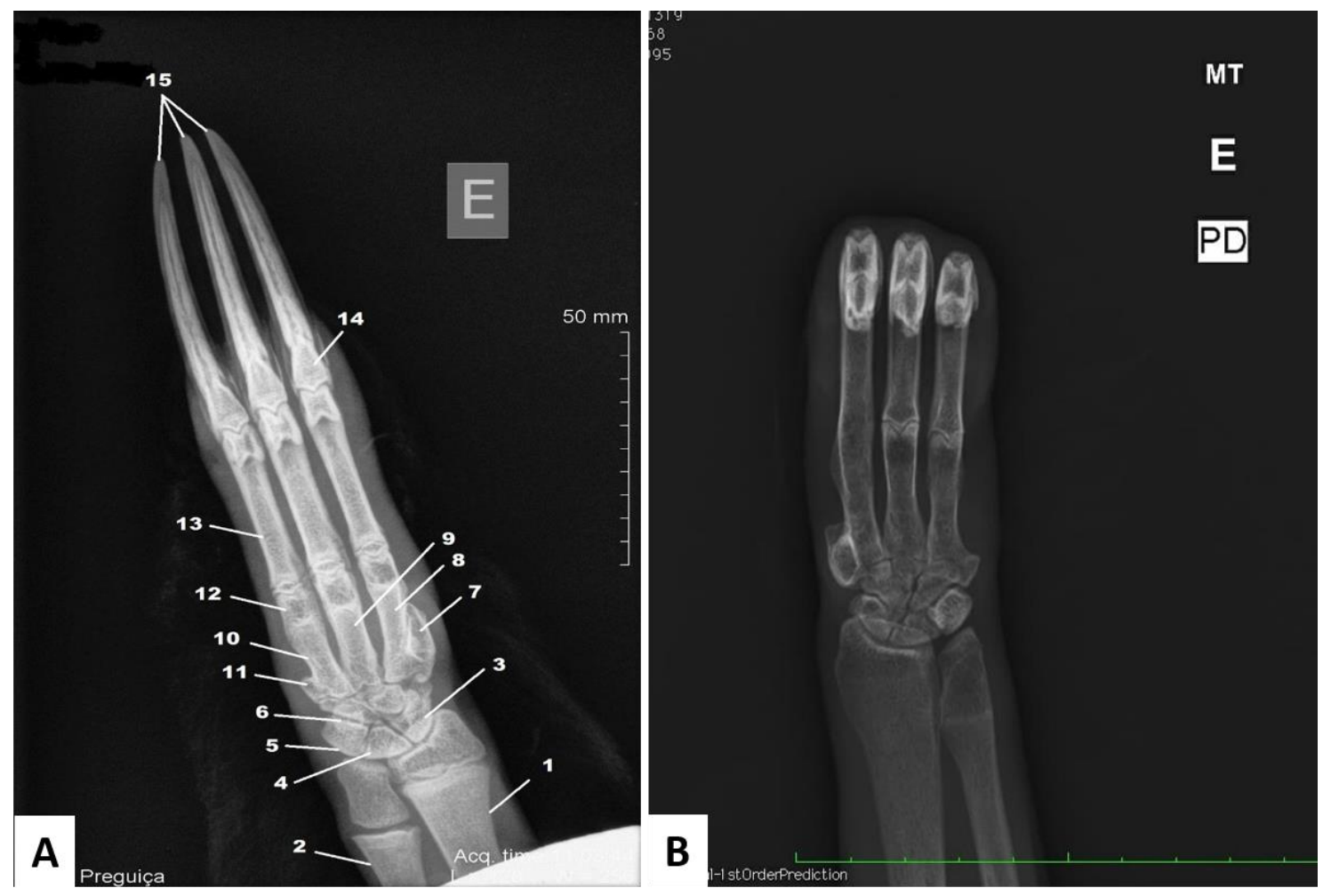

Source: Santos, Ferreira, Frosch, Jarreta, Baron, Guimarães (2022). 
Fig. 2-A: Image of the claw of B. variegatus in 2D by inkscape ${ }^{\circledR}$. B: 3D image of $B$. variegatus claw prosthesis model with Blender®.
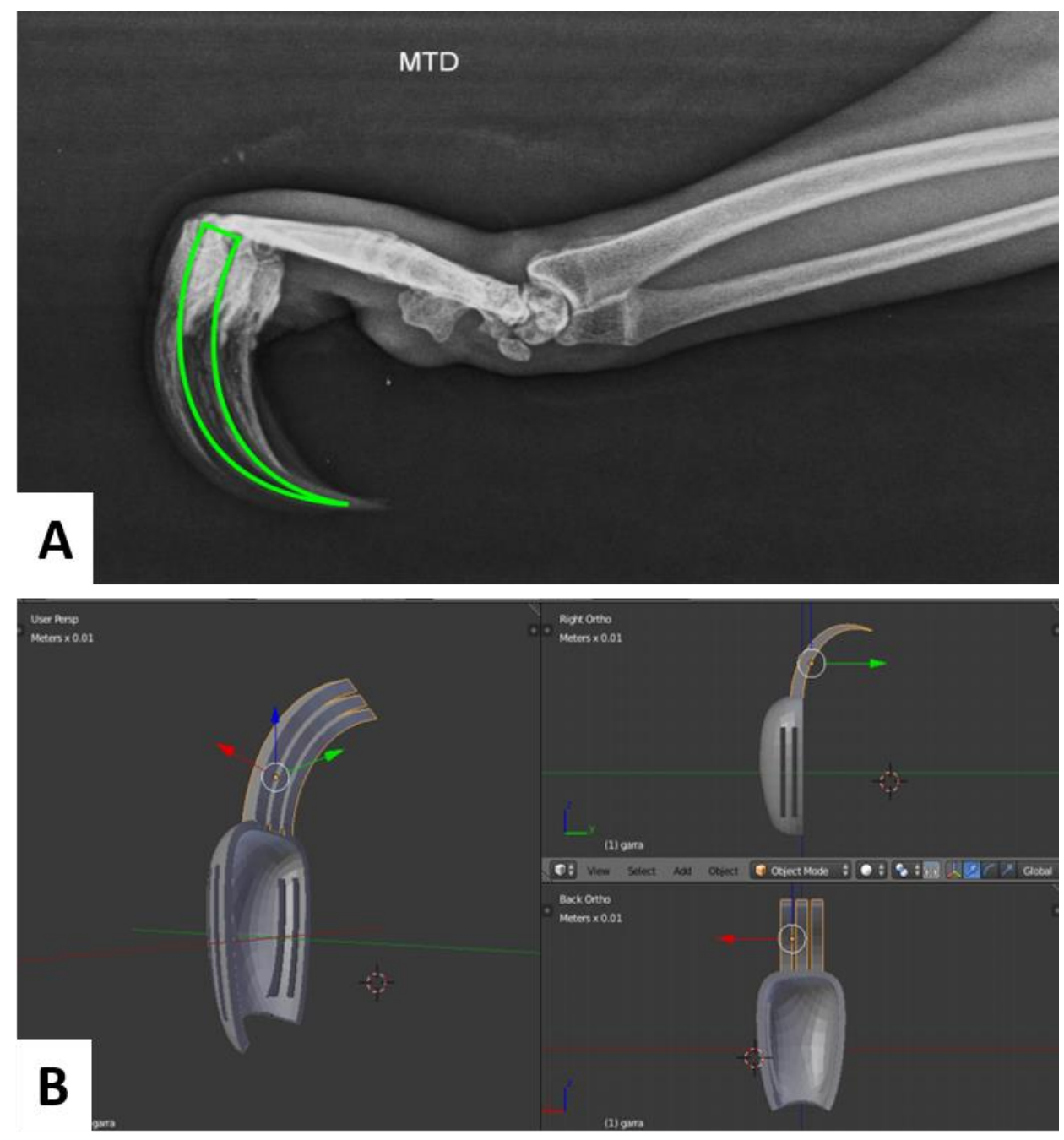

Source: Santos, Ferreira, Frosch, Jarreta, Baron, Guimarães (2022).

With the digitally generated 3D model, a physical model of the prosthesis was performed using the Cliever CL2 Pro Plus ® (Fig. 3A) printer, which has as its manufacturing principle the Technique Fused Deposition Modeling - FDM, characterized by the overlap of fused layers - in the case of this research, of polylactic acid (PLA) - with a height of approximately $0.2 \mathrm{~mm}$. After this process, the prosthesis received a finish of its shape and fill of orifices with the 3D Pen®. 
Fig. 3-A: Preparation of printing by Cliever Studio (PRO)®. B: Model of 3D prosthesis for the extremity of thoracic limbs of B. variegatus.
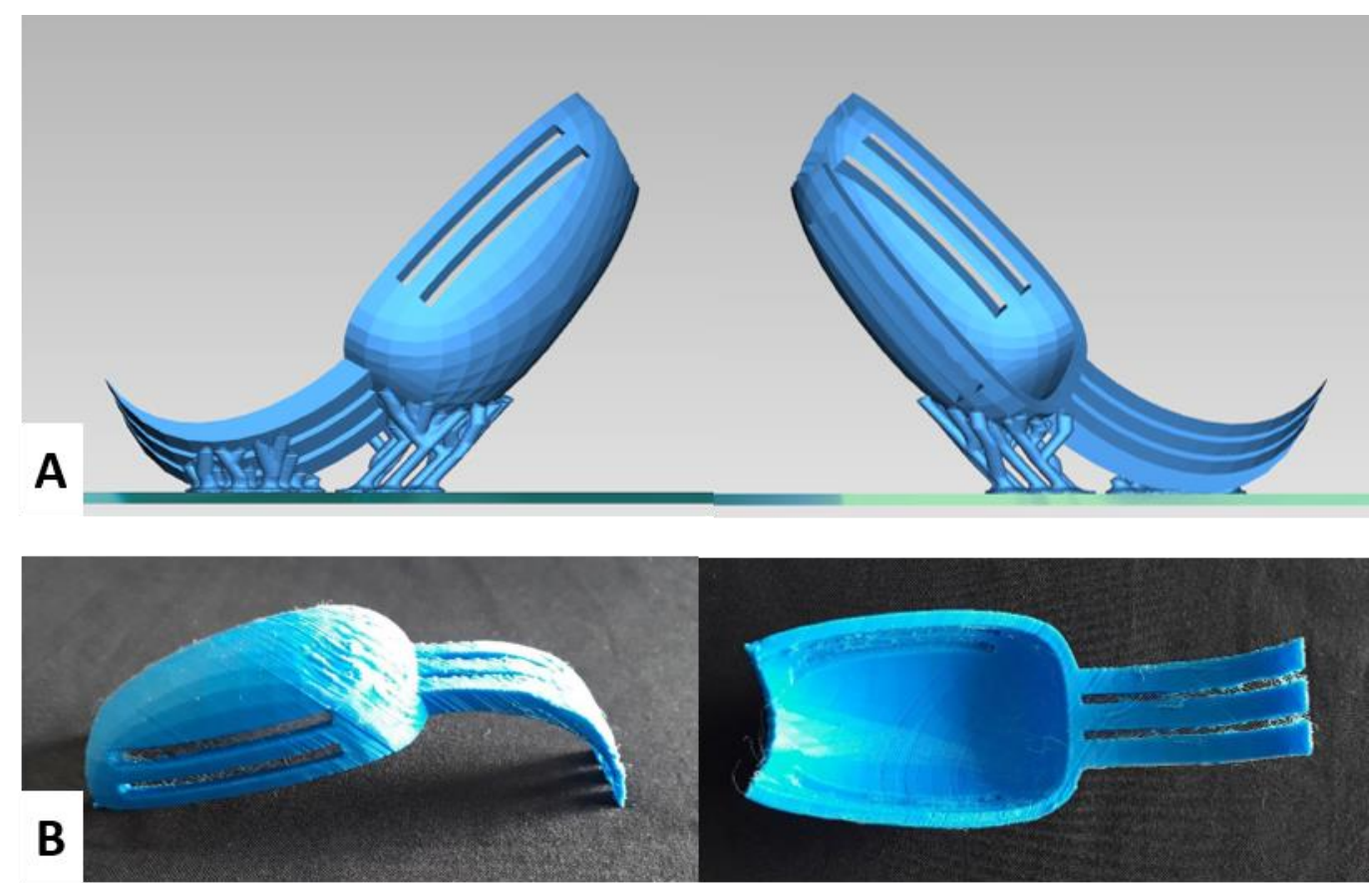

Source: Santos, Ferreira, Frosch, Jarreta, Baron, Guimarães (2022).

It is worth considering that there are, in the market, a variety of materials to be used as filament, with characteristics such as strength and quality of finish that vary according to the use and function for which they are intended. Among others, there is Acrinolitrin Estyrene Butadiene (ABS), Polyethylene Terephthalate with Glycol (PETG) and Lactic Polyacid (PLA), which was applied in the research for the manufacture of the biomodel. It should also be emphasized that, in preliminary tests, in relation to resistance in compression tests, ABS proved to be the preferred option. On the other hand, PLA presented lower deformation and better performance in three-point bending tests (MARTINEZ et al.,2017), and is therefore the most indicated material for the model to which it would be intended.

The biomodel has three claws and an area to fit the animal's limb, as well as cracks for velcro placement to attach it to the specimen (Fig. 3B).

In a research conducted by Reis et al. (2017) and Veneziani (2017) anatomical structures were scanned in a 3D scanner for subsequent 3D printing by an appropriate printer, and no imaging tests were used, unlike the present study, in which radiography was used to obtain two- and three-dimensional images, using software, with subsequent 
support formation processes, slicing for print preparation, followed by 3D printing of the final model and finishes, corroborating such procedures with Antas (2007).

Printing of the claws of $B$. variegatus, with a 3D printer Cliever CL2 ProPlus ${ }^{\circledR}$, the prosthesis model was obtained for these structures, which was thermoplastic, where the use of cited material was in accordance with that used by Reis et al. (2017) in their research.

\section{CONCLUSION}

As pointed out in the present study, Bradypus variegatus is often the victim of trampling and electric shocks, a fact that often compromises its extremities, causing the specimen to require veterinary medical interventions, for which knowledge is important regarding the anatomy of the species.

According to radiographic images analyzed in the present study, it was possible to observe that in this species the humerus bone is considerably long and that the radio and ulna bones are not fused, unlike some species and compatible with that presented in the anteater (Myrmecophaga tridactyla), agoutis (Dasyprocta spp) and in man. In addition, it is possible to visualize fissary discs, demonstrating the animal as young. Five metacarpals were found in the images of the extremities of thoracic limbs, with rudimentary I and V and II, III and IV developed.

With the use of radiographic images, it was possible to obtain the bi- and threedimensional images, thus continuing the process of rapid prototyping of the biomodel of the prosthesis of $B$. variegatus claws. The final product was developed in thermoplastic material, in which, at one end, the space for fitting the animal member is present, while at the other end are the replicas of the claws.

Thus, the present work allowed greater anatomical knowledge of this species, as well as provided an initial anatomical biomodel, and may in future help in the actions of conservation of the species and individuals welfare. 


\section{REFERÊNCIAS}

ANTAS, A.F.F. Utilização das tecnologias de prototipagem rápida na área médica. Faculdade de Engenharia da Universidade do Porto, Portugal, 2007.

ARAÚJO, G.D.; KANAYAMA, C.Y.; MACHADO, F.M.E. Trauma elétrico em macaco bugio (Alouatta guariba, HUMBOLDT, 1812): relato de caso. In: Anais do I SINCA - Simpósio Nacional em Ciência Animal. Universidade Federal de Uberlândia, Minas Gerais, 2010.

AZARIAS, R.E.G.R.; AMBRÓSIO, C.E.; MARTINS, D.S.; OLIVEIRA, V.L.; BENETTI, E.; FERREIRA, J.R.; MIGLINO, M.A. Morfologia dos dentes do bicho preguiça de coleira (Bradypus torquatus), Illiger, 1811. Revista Biotemas, v. 19, n.4, p. 73-84, 2006.

CURITIBA. Rede de Proteção Animal - Cidade de Curitiba, 2012. Disponível em: http://www.protecaoanimal.curitiba.pr.gov.br/Conteudo/ProtecaoAnimal.aspx DÂNGELO, J.G.; FATTINI, C.A. Anatomia humana sistêmica e segmentar. São Paulo: Atheneu, p. 763, 2007.

FREITAS, K.B.; RAMOS, D.A.; SILVA, E.G.; FAVORETTO, S.M.; CAMPOS, D.B. Estudo anatômico do membro pélvico do bicho preguiça-de-garganta-marrom (Bradypus variegatus, SCHINZ, 1825). Anais do 38 ${ }^{\circ}$ CBA, p.284, 2017.

FROSCH, R. O mundo em 3d: produção de recursos pedagógicos inclusivos. Campos dos Goytacazes: Encontrografia Editora Ltda, 2021.

GRANDO, N. Segmentação de Imagens Tomográficas visando a construção de modelos médicos. Tese de Pós-Graduação em Engenharia Elétrica e Informática Industrial, Centro Federal de Educação Tecnológica do Paraná, Curitiba, 2005.

JÓIA FILHO, P. Reconstrução e construção de malhas em estruturas biomecânicas tridimensionais para análise por elementos finitos. Dissertação (Mestrado) Universidade Estadual Paulista. Faculdade de Engenharia, Bauru, 2008.

MARTINEZ, A.C.P.; SOUZA, D.L.; SANTOS, D.M.; PEDROTI, L.G.; CARLO, J.C.; MARTINS, M.A.D. Avaliação do comportamento mecânico dos polímeros ABS e PLA em impressão 3D visando simulação de desempenho estrutural. Gestão e Tecnologia de Projetos, São Carlos, v. 14, n.1, p.125-141, 2019.

PETRUCCI, M.P.; PONTES, L.A.E.; QUEIROZ, F.F.; CRUZ, M.C.; SOUZA, D.B.; SILVEIRA, L.S.; RODRIGUES, A.B.F. Electrocution accident in free-ranging bugio (Alouatta fusca) with subsequente amputation of the forelimb: case report. Revista

Portuguesa de Ciências Veterinárias, v.104, p. 87-90, 2009.

REIS, D.A.L.; GOUVEIA, B.L.R.; ALCÂNTARA, B.M.; SARAGIOTTO, B.P.; BAUMEL, E.E.D.; FERREIRA, J.S.; ROSA JÚNIOR, J.C.; OLIVEIRA, F.D.; SANTOS, P.R.S.; ASSIS NETO, A.C. Biomodelos ósseos produzidos por intermédio da impressão 3D: uma alternativa metodológica no ensino da anatomia veterinária. Rev. Grad. USP, v. 2, n.3, p.47-53, 2017. 
SCAGLIUSI, N. Do cinzel ao bit: a revolução das tecnologias digitais no design de jóias. Dissertação (Mestrado) - Pontífica Universidade Católica, Rio de Janeiro, 2015.

SEARS, N.A.; SESHADRI, D.R.; DHAVALIKAR, O.S.; COSGRIFF-HERNANDEZ, E. A Review of Three-Dimensional Printing in Tissue Engineering". Tissue Engineering. Part B, Reviews, v. 22, p. 298-310, 2016.

SHIN-WOOK, K.; HUN-JOO, S.; CHUL, S.K.; SEOK, H.S. A customized Bolus Produced Using a 3-Dimensional Printer for Radiotherapy. Plos One, v.9, n. 10, 2014. VENEZIANI, G.R. Desenvolvimento de um objeto simulador "canis morphic" utilizando impressora 3D para aplicação em dosimetria na área de radioterapia veterinária. Instituto de pesquisas energéticas e nucleares. Autarquia associada à Universidade de São Paulo, 2017. 